\title{
大規模総合大学施設のエネルギー消費実態に関する研究 電力日負荷曲線の実測データを用いた大阪大学のエネルギー消費特性分析 STUDY ON ENERGY CONSUMPTION CHARACTERISTICS OF LARGE-SCALE UNIVERSITY FACILITIES
}

Energy consumption characteristic analysis of Osaka University using the survey data of the daily electricity load curve

\section{大橋 巧*，宮崎正幸**，下田吉之塻 \\ Takumi OHASHI, Masayuki MIYAZAKI and Yoshiyuki SHIMODA}

\begin{abstract}
Daily electricity load curves of buildings in Osaka University campus are analyzed. By classifying university facilities into three categories according to kind of departments, energy consumption characteristic of each category becomes clear. Moreover, it turned out that the apparatus which is working for 24 hours occupies most part of annual power consumption and peak demand power in the University.
\end{abstract}

Keywords : University Facilities, Sustainable Campus, Energy Consumption, Daily load curve 大学施設，サステイナブルキャンパス，エネルギー消費，日負荷曲線

\section{1. はじめに}

大学は持続可能な低炭素化社会実現に向け、教育・研究活動を通 じて社会貢献することが求められる。同時に社会の一躍を担う立場 として、エネルギーの使用の合理化に関する法律や自治体条例等の 遵守を前提に、大学施設でのエネルギー消費量や温室効果ガス排出 量を削減することは不可避な状況にある。建物運用において具体的 な省エネルギー計画を策定し実行に移すには、個々の建物のエネル ギー消費実態やその特性を把握することが極めて重要となる。

このことから大学施設のエネルギー消費量解析に関する報告も多 く、建物用途別や部局別に一次エネルギー消費量を調查した事例 ${ }^{1)}$ 2)、大学内の二つの建物の時刻別電力量を分析した事例 ${ }^{3)}$ 、外気温 度や学生数などの変動要素がエネルギー消費量に与える影響を分析 した事例 ${ }^{4)}$ 、保有機器調查結果や季節変動要素の分析により用途別 電力消費量を推計した事例 ${ }^{5}$ )、月別電力消費量をもとに非空調用エ ネルギー量を推定した事例 ${ }^{6)}$ 、空調機器の成績係数を用いて冷暖房 需要を推定した事例 7)などの既往研究により、その消費特性も明ら かにされつつある。しかし、その分析に用いる根拠は年別・月別・ 日別の実測データが主であり、大学全体を対象とし、かつ建物単位 での時刻別電力日負荷曲線を用いて分析した既往研究は見当たらな い。

大阪大学では平成 23 年 6 月中旬より、主要 3 キャンパス (吹田・ 豊中・箕面)、延床面積約 93 万 $\mathrm{m}^{2} の$ 建物群において、主要建物ごと
（計 246 箇所）に 30 分単位で電力消費量を計測・集約し、学内構成 員向けポータルサイトにてリアルタイムに情報を閲覧できるシステ ム（以下、電力可視化システム）を導入している。本研究は大規模 総合大学のエネルギー消費特性実態を把握することを目的に、文科 系学部 - 研究科、理科系学部 - 研究科、大規模研究施設、附属病院 等、多様な施設から成る大阪大学の実測データを活用し各種解析を 行った結果について報告する。

総合大学である本学は、主要 3 キャンパスで敷地面積約 158 万 $\mathrm{m}^{2}$ を保有する一つの都市であり、電力消費分析から得られる知見やそ の技法は、他大学のみならず一般の都市エネルギーシステムの分析 にも発展・応用できるものと考えられる。

\section{2. 大阪大学のエネルギー消費推移}

大阪大学主要 3 キャンパスの一次エネルギー消費量注 1) と延床面 積の推移を図 1 に、主要 3 キャンパス全体の一次エネルギー消費量 原単位の推移を図 2 に、キャンパスごとの一次エネルギー消費量原 単位の推移を図 3 に、構成員一人当たりの一次エネルギー消費量の 推移を図 4 に示寸。なお、本報告における一次エネルギー消費量は 電力と都市ガスの合計值を示しており、学内で使用する燃料系エネ ルギー（灯油、軽油、重油、ガソリン）は、全体の $0.1 \%$ に満たな い(平成 22 年度実績）ため省略している。また、平成 19 年度は実 験施設がなくエネルギー消費密度が低い大阪外国語大学が箕面キャ
* 大阪大学環境・エネルギー管理部 特任講師・工修

** 大阪大学大学院工学研究科環境・エネルギー工学専攻 大学院生

*** 大阪大学大学院工学研究科環境・エネルギー工学専攻 教授. 工博
Specially Appointed Assoc. Prof., Department of Environment and Energy Management, Osaka University, M. Eng.

Stu., Division of Sustainable Energy and Environmental Engineering, Graduate School of Engineering, Osaka University

Prof., Division of Sustainable Energy and Environmental Engineering, Graduate School of Engineering, Osaka University, Dr. Eng. 
ンパスとして大阪大学と統合した影響がある。

附属病院、理科系部局、理科系研究施設等が集約する吹田キャン パスは、平成 23 年度実績で大学全体の一次エネルギー消費量のうち

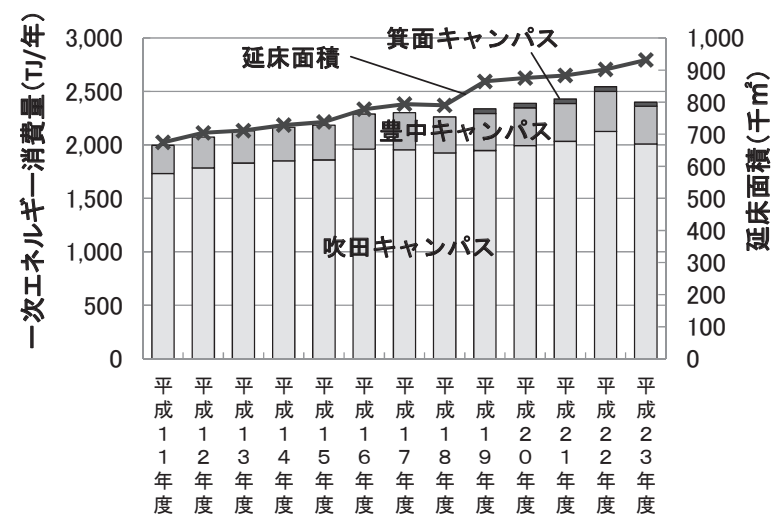

図 1 一次エネルギー消費量と延床面積の推移

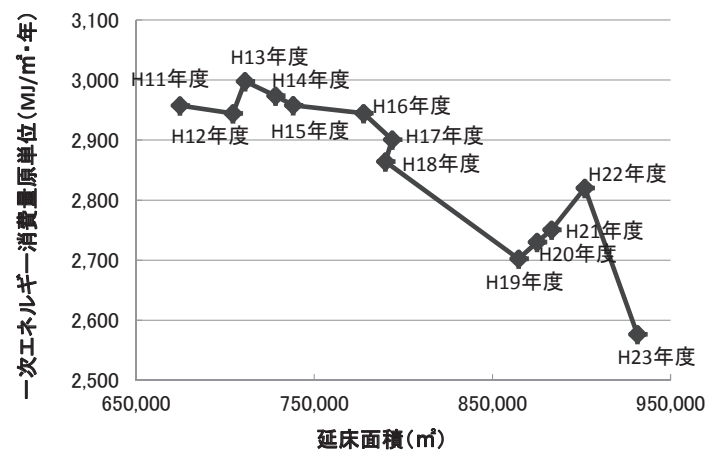

図 2 一次エネルギー消費量原単位の推移

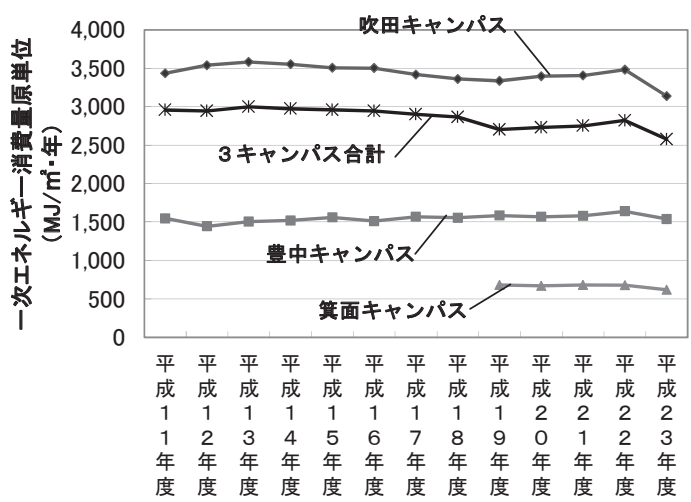

図３＼cjkstart各キャンパスの一次エネルギー消費量原単位の推移

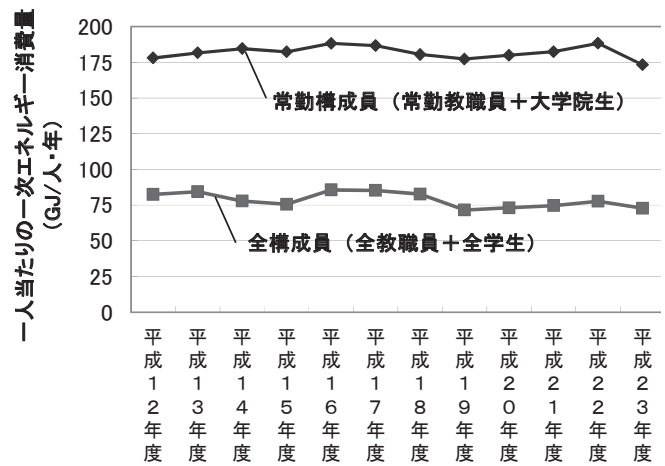

図 4 一人当たりの一次エネルギー消費量の推移
約 $84 \%$ を占め、文科系の部局が過半を占める豊中キャンパスに比心゙、 一次エネルギー消費量原単位は倍以上の值となっている。大学全体 では延床面積の増に伴い、一次エネルギー消費量は増加傾向にある が、単位面積当たりの原単位では、平成 19 年度と平成 23 年度を除 くとほぼ横ばい状態と言える。詳細は後述するが、平成 23 年度は東 日本大震災の影響により全学的な節電対策を行った年であり、大き なエネルギー削減効果が現れている。なお、構成員一人当たりのエ ネルギー消費量については顕著な増減は見られない。

\section{3. 一次エネルギー消費量原単位による部局分類}

大学には多様な施設が混在しており、エネルギーの消費実態も異 なる。図 5 に、平成 23 年度の大阪大学における各部局の延床面積と 一次エネルギー消費量の関係を示す。ここで文科系、理科系、大規 模施設（医学部附属病院、全国共同利用施設）ではエネルギー消費 密度に顕著な差違を読み取ることができる。そこで本報告ではエネ ルギー消費密度の違いにより文科系：カテゴリーI、理科系：カテ ゴリーII 、大規模施設 : カテゴリーIII と定義し、エネルギー消費特 性分析を行う。なお、大規模施設は大半が中央熱源プラントを保有 する施設となっている。各カテゴリーに含まれる建物分類および部 局名を表 1 に示す。

一次エネルギー消費量原単位の平均值は、カテゴリー I ：765MJ/ $\mathrm{m}^{2}$ ・年、カテゴリーII $: 2,413 \mathrm{MJ} / \mathrm{m}^{2}$ ・年、カテゴリーIII $: 5,738 \mathrm{MJ} /$ $\mathrm{m}^{2}$ ・年となっており、理科系は文科系の 3 倍以上の值を示し、大き な差違があることが分かる。

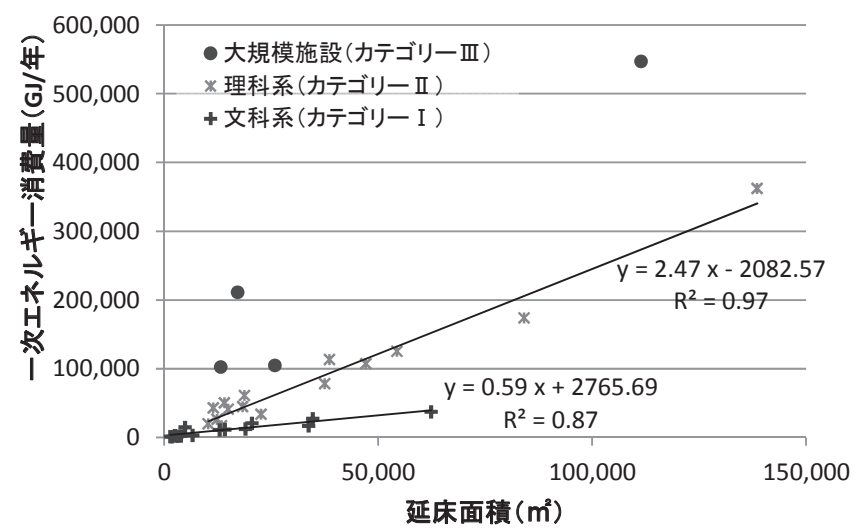

図 5 各部局の延床面積と一次エネルギー消費量

表 1 カテゴリー分類

\begin{tabular}{|c|c|c|}
\hline カテゴリー & 建物分類 & 部局名称 \\
\hline \multirow[t]{2}{*}{$\begin{array}{l}\text { カテゴリーI } \\
\text { (文科系) }\end{array}$} & 文科系·文科系研究施設 & $\begin{array}{l}\text { 文科系学部·研究科(文学·人間科学·外国語学·法 } \\
\text { 学·経済学)、言語文科研究科、社会経済研究所等 }\end{array}$ \\
\hline & 本部-福利施設-共同施設 & $\begin{array}{l}\text { 本部事務機構、保健センタ一、福利会館、総合学術博 } \\
\text { 館等 }\end{array}$ \\
\hline \multirow{9}{*}{$\begin{array}{l}\text { カテゴリーII } \\
\text { (理科系) }\end{array}$} & 理学系 & 理学部、理学研究科 \\
\hline & 医学系 & 医学部、医学研究科 \\
\hline & 歯学系 & 歯学部、歯学研究科、歯学部附属病院 \\
\hline & 薬学系 & 薬学部、薬学研究科 \\
\hline & 工学系 & 工学部、工学研究科 \\
\hline & 基礎工学系 & 基礎工学部、基礎工学研究科 \\
\hline & 情報科学系 & 情報科学研究科 \\
\hline & 生命機能系 & 生命機能研究科 \\
\hline & 理科系研究施設 & $\begin{array}{l}\text { 微生物研究所、産業科学研究所、蛋白質研究所、接 } \\
\text { 合科学研究所、免疫フロンティア研究センター、理科 } \\
\text { 系研究センタ一等 }\end{array}$ \\
\hline \multirow{2}{*}{$\begin{array}{l}\text { カテゴリーIII } \\
\text { (大規模施設) }\end{array}$} & 医学部附属病院 & 医学部附属病院 \\
\hline & 全国共同利用施設 & $\begin{array}{l}\text { 核物理研究センター、サイバーメディアセンター、レー } \\
\text { ザーエネルー学研究センター }\end{array}$ \\
\hline
\end{tabular}




\section{4. 平成 23 年度の節電対策による効果}

本章では前述した平成 23 年度節電対策の効果について述べる。大 阪大学では監督官庁および関西電力の要請を受け、夏季（ 7 ～

月）: 最大需要電力 $\cdot$ 前年比 $15 \%$ 削減、冬季（12月～ 3 月）：最大需 要電力・前年同月比 $10 \%$ 削減という数值目標を掲げた節電活動を実 施した。設備改修工事などのハード的対策はごく僅かで、空調設定 温度の緩和、照明の間引き、実験のスケジュール変更、自家発電機 の活用等、使用抑制が主な対策であったが、電力可視化システムを 活用することで、結果として吹田・箕面キャンパスは全日目標を達 成するなど大きな節電効果を得た。

今回の対策は、社会的要請に添い最大需要電力の低減が主目的で あったが、都市ガスを含めた一次エネルギー消費量原単位の削減に も繋がっている。図 6 に前年度との比較をカテゴリー別に示す。電 カはカテゴリー間の差は小さく、夏季は 14〜16\%削減、冬季は 6〜 $7 \%$ 削減という結果となった。なお、カテゴリーIIIは一部の研究施設 において夏季の実験量を減らし、逆に冬季の実験量を増やしたこと が影響している。都市ガスについては、削減率は一律ではなくカテ ゴリー間での使用用途の差が影響しているものと考えられる。

図 7 には月別の一次エネルギー消費量原単位の推移(前年度比較) を示す。都市ガスは、 $7 \sim 9 、 12 \sim 3$ 月の節電期間以外は前年度と の差が小さいが、電力については、夏季の節電期間後も一定の削減 量があり、照明の間引きや各種設定調整などによる削減効果が継続 していることを示唆する。

図 8 では、平成 23 年度の一次エネルギー消費量原単位の対前年度 比率を示す。大学全体では約 $9 \%$ の削減であるが、全ての建物分類 で減少しており、その差違は比較的小さいことが確認できる。

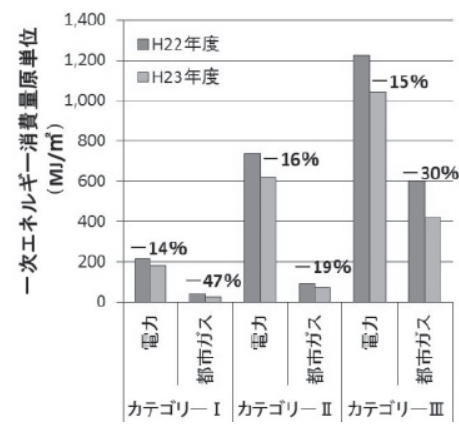

夏季 (7〜9月)

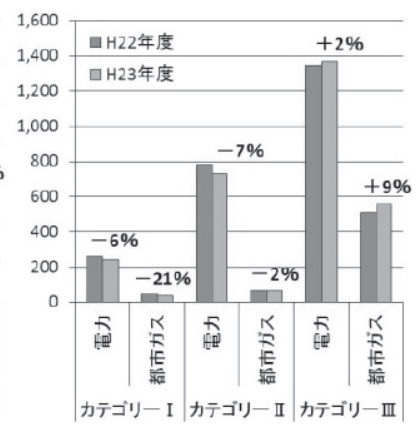

冬季 (12 3 月)
図 6 平成 23 年度の一次エネルギー消費量原単位の削減実績

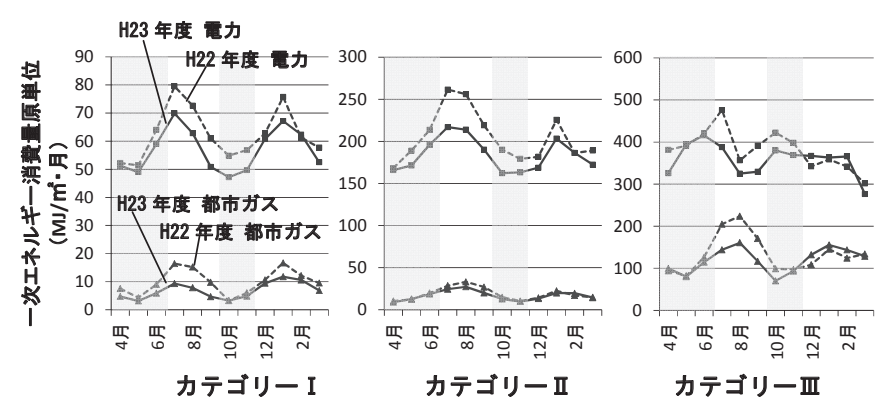

図 7 平成 23 年度の月別一次エネルギー消費量原単位 （前年度比較）

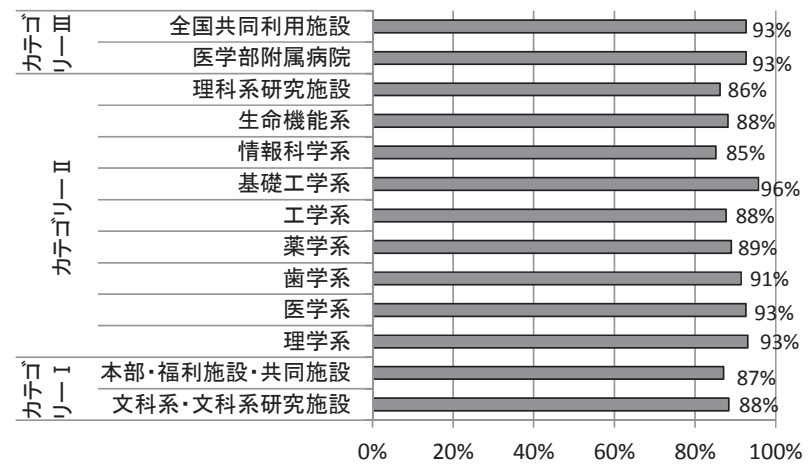

図 8 平成 23 年度一次エネルギー消費量原単位の対前年度比率

\section{5. 大阪大学のエネルギー消費に関する分析}

本章では最新の平成 23 年度以降のデータを用い、大阪大学のエ ネルギー消費特性に関して分析を行う。東日本大震災の影響による 節電対策を行った年のデータをもとにしていることに留意する必要 があるが、図 8 で示した通り建物分類間での削減率の差は比較的小 さく、消費特性の比較分析おいては有意であると考える。

5.1 一次エネルギー消費量

平成 23 年度のカテゴリー別の延床面積の割合を図 9 に、年間一次 エネルギー消費量の割合を図 10 に示す。延床面積の割合はカテゴリ —I：24\%、カテゴリーIII：58\%、カテゴリーIII：18\%に対し、一 次エネルギー消費量の割合はカテゴリー I ： 7 \% 、カテゴリーII： $53 \%$ 、カテゴリーIII：40\%となっており、大学全体の省エネルギー を検討する上では、カテゴリーIII III の影響が大きいことが分かる。

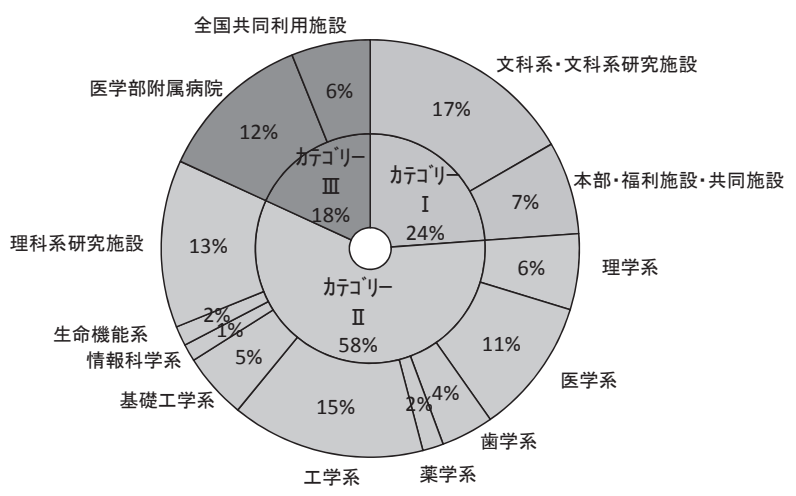

図 9 延床面積の割合

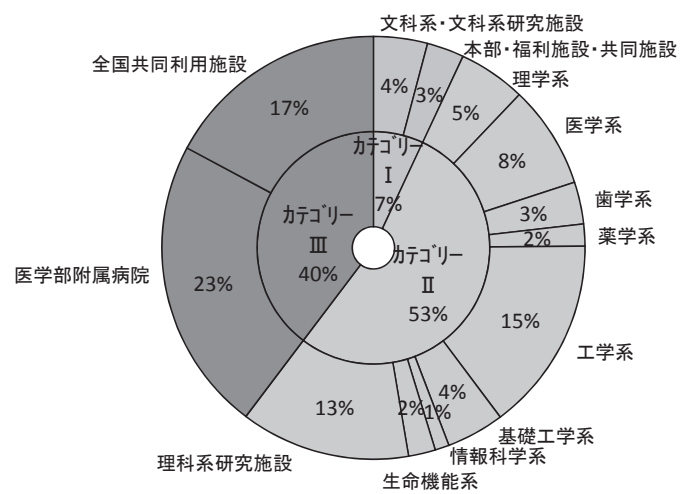

図 10 年間一次エネルギー消費量の割合 
図 11 には建物分類ごとの一次エネルギー消費量原単位を示す。加 速器装置、大型計算機、高出力レーザー等を利用する全国共同利用 施設はエネルギー消費密度が極めて高く、カテゴリーII では生命機 能系を除き $2,000 \sim 2,700 \mathrm{MJ} / \mathrm{m}^{2}$ ・年程度、文科系・文科系研究施設 は $649 \mathrm{MJ} / \mathrm{m}^{2}$ ・年と、用途によって特徽的な差がある。なお、カテ ゴリーII の内、生命機能系や理科系研究施設の中でも試料保存用の フリーザーを多く保有する施設は $3,000 \mathrm{MJ} / \mathrm{m}^{2}$ ・年を超えるものが多 く、24 時間稼働機器の影響が大きいものと考えられる。大阪大学全 体の平均值は $2,619 \mathrm{MJ} / \mathrm{m}^{2}$ ・年であるが、文献值 ${ }^{8)}$ では、病院 (一 般) : $3,060 \mathrm{MJ} / \mathrm{m}^{2}$ - 年、大学 (医学系) $3,550 \mathrm{MJ} / \mathrm{m}^{2}$ - 年、大学 (医 学系除く) : $1,300 \mathrm{MJ} / \mathrm{m}^{2}$ ・年を示しており、特に、大阪府災害拠点 病院に指定され、三次救急医療機関として 24 時間体制で高度医療を 行う本学の医学部附属病院は、文献值に比べて高い傾向が確認でき る。

図 12 には構成員一人当たりの一次エネルギー消費量を示す。理科 系研究施設や全国共同利用施設は一人当たりの消費量が多く、逆に 文科系・文科系研究施設は学部生を含む全構成員当たりでは非常に 小さな值を示すことが分かる。なお、医学部附属病院、及び歯学部 附属病院を含む歯学系は患者数を考慮していないため参考值とする。

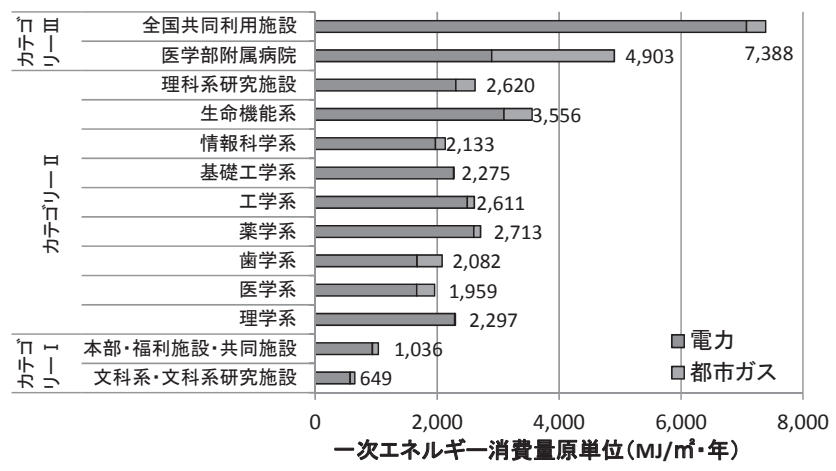

図 11 建物分類ごとの一次エネルギー消費量原単位

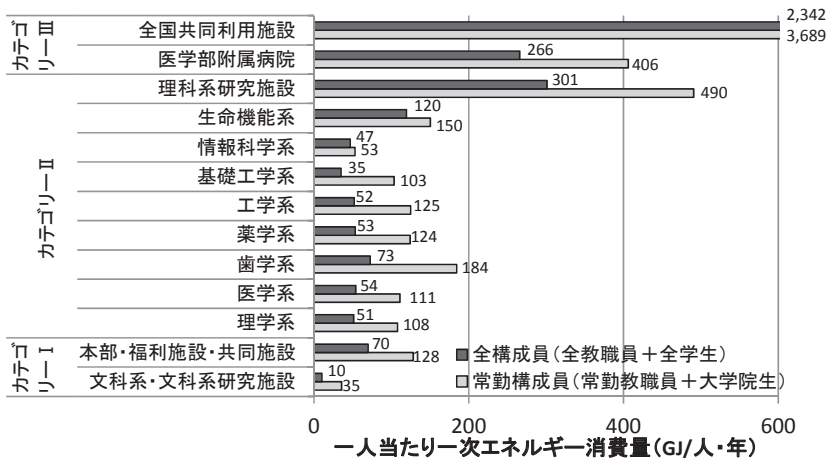

図 12 建物分類ごとの一人当たりの一次エネルギー消費量

\section{2 電力消費}

本節では、平成 23 年度実績において大阪大学の一次エネルギー 消費量の約 $85 \%$ を占める電力消費について述べる。なお、分析には 電力可視化システムのデータを用いるが、本システムは平成 23 年 6 月中旬に供用を開始しているため、本節の分析には平成 23 年 7 月〜 平成 24 年 6 月の 1 年間の実測データ注 2) を用いている。

\section{2 (1) 需要率}

図 13 に平成 23 年度夏季におけるフィーダーごとの変圧器容量と 需要率の関係を示す。省エネルギーを目的に無負荷損を抑えるため には、適切な変圧器容量の設定が望ましいが、相対的に変圧器容量 が小さいカテゴリー I では、需要率をやや高く保てる傾向にあるこ とが分かる。特に理科系施設では、将来の電源増設対応目的以外に も、計画時における安全率の過大な設定が影響しているものと推察 され、容量の適正化が課題と言える。

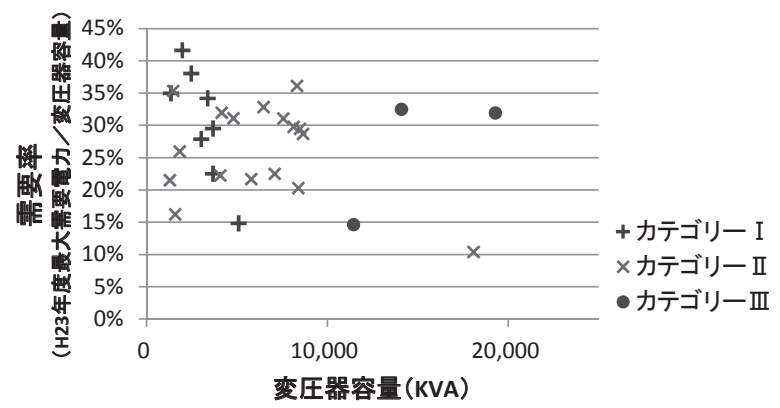

図 13 フィーダーごとの変圧器容量と需要率の関係

\section{2 (2) 時刻別電力消費}

電力消費特性を詳細に把握するため、電力可視化システムで得ら れる時刻別電力消費データを用いて分析を行った。

図 14 に、カテゴリーごとの各月の平均值および 1 月 1 日の電力日 負荷曲線を示す。カテゴリー間では時刻別消費電力の最小值(以下、 ベース電力）に大きな差違があることが分かる。ベース電力は平日 と休日注3)の比較において差は小さい。また 1 月 1 日は年間で活動量 が最も少ない日であると考えられるが、一日を通してほぼ一定量の 消費があることから、年間を通して昼夜問わず人の活動に関わらず 発生する電力消費が、終日一定量存在することが推察できる。

図 15 においては、より詳細に建物分類間の負荷特性の差違を確認 するため、大阪大学全体の実績において、電力量・最大需要電力量 とも最大を記録した 7 月を抽出し、月平均の電力日負荷曲線を建物 分類ごとに示した。ベース電力分を除く日中の変動分をみると、建 物分類間の差は比較的小さいことが分かる。また、医学部附属病院 や歯学部附属病院を抱える歯学系は他施設と比べて立ち上がり時刻 が早いなどの特徴も読み取ることができる。

次式（1）（2）により与える、夜間の最小電力消費率： $R_{N i}$ と休日 ピーク時の電力消費率： $R_{H o}$ の 7 月における関係を図 16 に示す。こ こで、平日の最小電力を $P_{W_{S}}\left[\mathrm{~W} / \mathrm{m}^{2}\right]$ 、平日・休日の最大電力をそれ ぞれ $P_{H / m} \cdot P_{H / m}\left[\mathrm{~W} / \mathrm{m}^{2}\right]$ とする。

夜間の最小電力消費率、休日ピーク時の電力消費率ともカテゴリ 一III >カテゴリーII > カテゴリー I の順に高くなっており、夜間の 電力消費率が高いと休日の電力消費率も高くなる傾向が把握できる。

$$
R_{N i}=\frac{P_{W s}}{P_{W m}} \quad \cdots \cdot(1) \quad R_{H o}=\frac{P_{H m}}{P_{W m}} \quad \cdots \cdot(2)
$$

\section{2 (3) 最大需要電力}

一般に電力平準化や基本料金低減のためには最大需要電力の抑制 が必要となるが、東日本大震災以降、社会的要請として以前にも増 して重要な意味合いを持つ。ここで、電力消費をその日負荷曲線の 

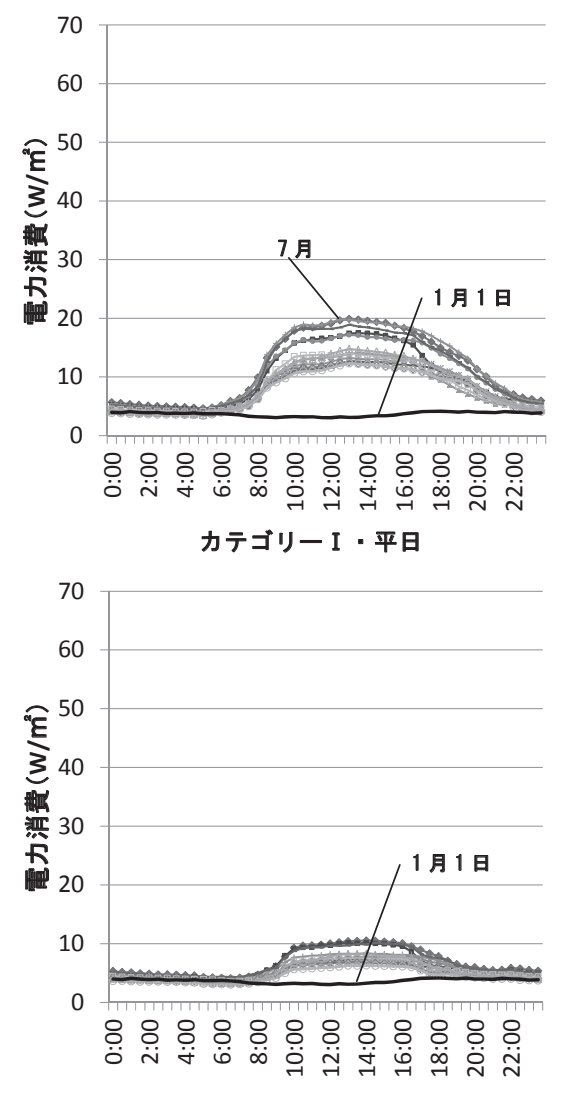

カテゴリーI・休目

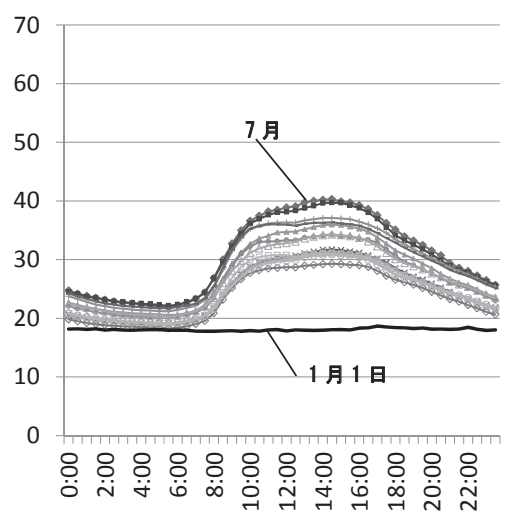

カテゴリーII ・ 平日

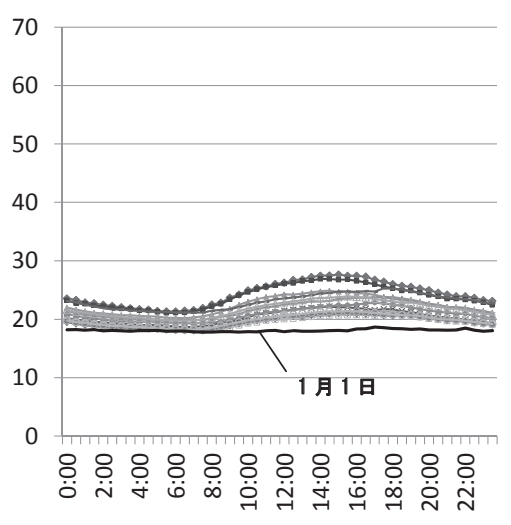

カテゴリーII・休目

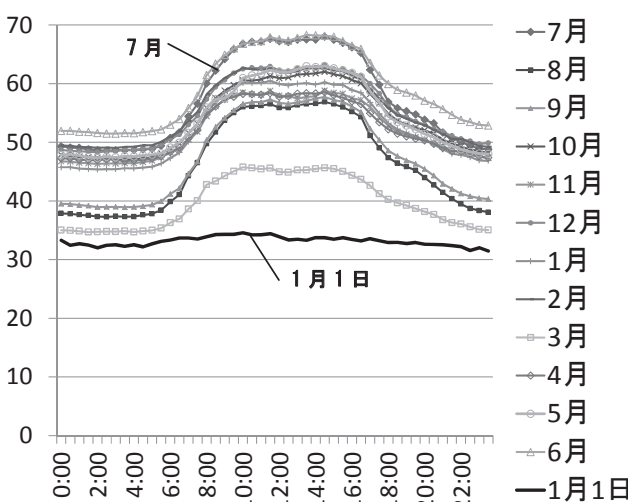

カテゴリーIIII・平日

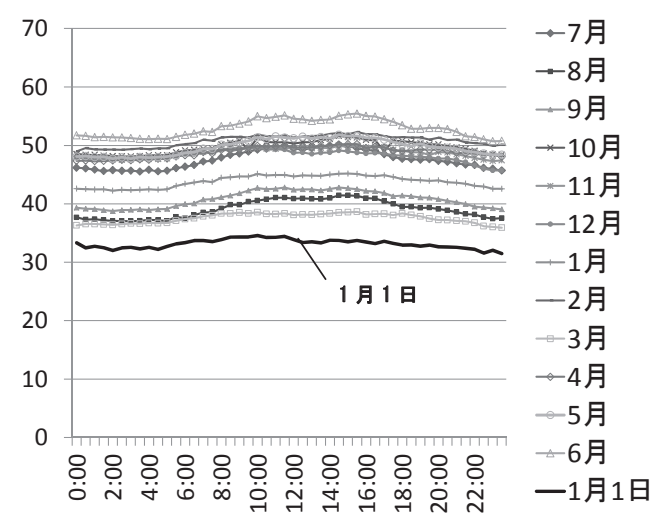

カテゴリー吕・休目

図 14 カテゴリーごとの電力日負荷曲線（上段：平日、下段 : 休日)

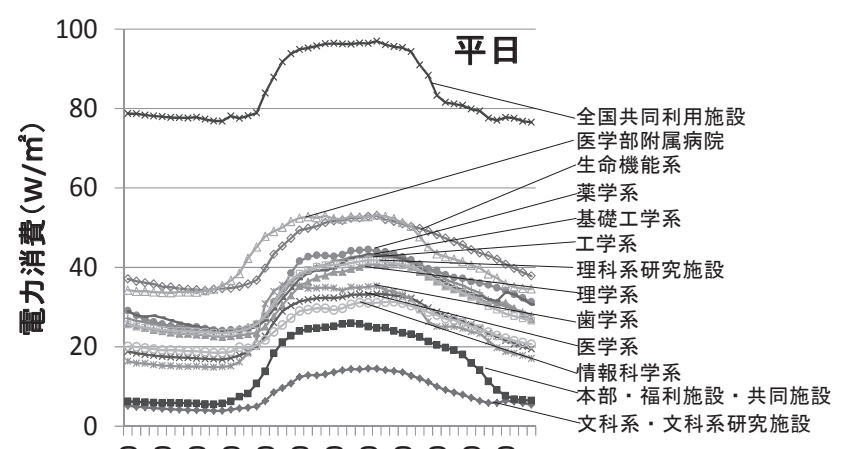

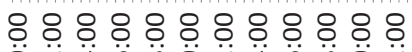

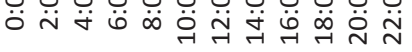

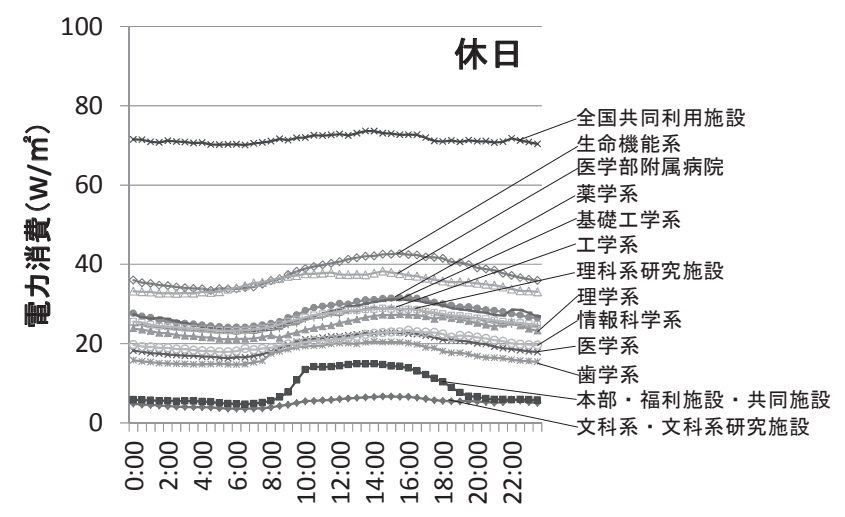

図 15 ピーク月（7 月）おける建物分類ごとの電力日負荷曲線 (上段：平日、下段：休日）

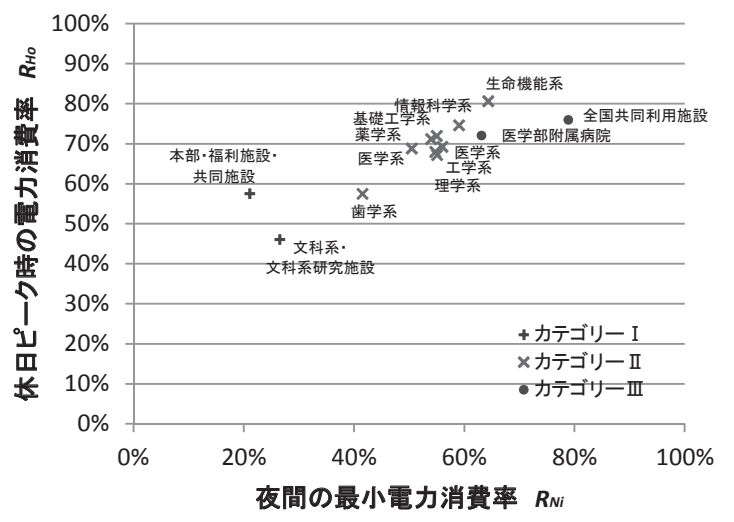

図 16 ピーク月（7月）おける夜間の最小電力消費率と

休日ピーク時の電力消費率の関係

特性によって、

・「1)ベース分」：人の活動に関係しない電力消費

・「(2)活動分」：人の活動に伴って必要となる空調以外の電力消費

・「(3)非 $24 \mathrm{H}$ 空調」：人の活動に伴って必要となる空調用電力消費 と分類し、図 17、図 18 において、カテゴリーI・II のピーク月（7 月平均）ピーク時の電力消費の内訳を推計する注 4 。

「(1)ベース分」は前項で得られた知見に沿い、休日のベース電力 の值とする。図 14 における需要の変動は気温変化に伴う空調用消費 電力の変動の影響が大きいと考えられるため、「活動分」は平日の需 要が最も少ない月（以降、非空調月）を参照（カテゴリーI：5月、 カテゴリーII：4月）し、当該月の平日ピーク電力から休日ベース 
電力の值を減じたものとする。 7 月のピーク電力から先に求めた「(1) ベース分」と「(2)活動分」を差し引いた值を「(3)非 $24 \mathrm{H}$ 空調」とし た。

結果、カテゴリーI では「(2)活動分」と「(3)非 24H 空調」で全体 の $79 \%$ を占め、最大需要電力の抑制には、一般照明・ OA 機器・一般 空調等、人の活動に伴って必要となる用途の対策が効果的であるの に対し、カテゴリーIIでは過半が「(1)ベース分」であり、最大需要 電力に対しても 24 時間稼働している機器の影響が大きいことを示 唆する。

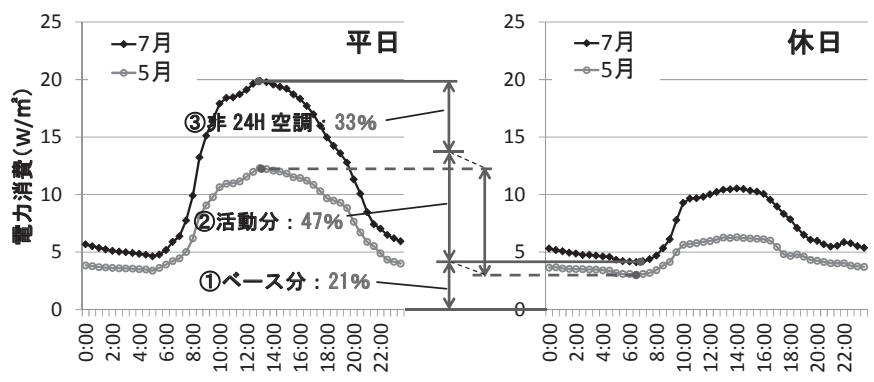

図 17 カテゴリーI のピーク時における電力内訳推計

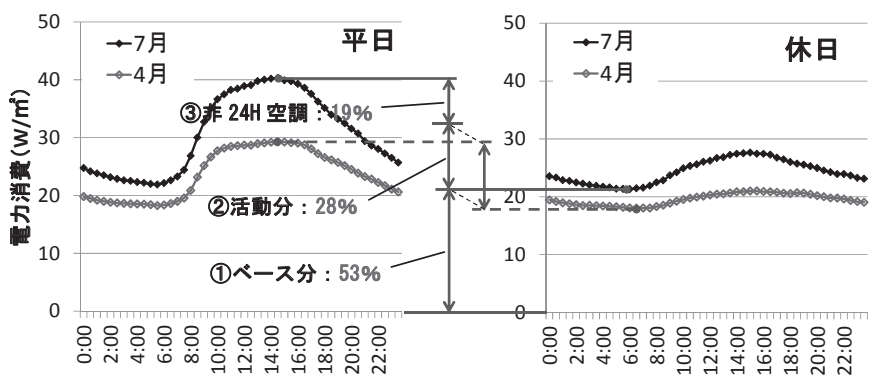

図 18 カテゴリーII のピーク時における電力内訳推計

図 19 では夏季 ( 7 〜 月) における大阪大学の日最大需要電力と 日最高気温 ${ }^{3}$ (5) の関係を示す注 6 ) 。最高気温の上昇に伴い、日最大需 要電力も増加する傾向が読み取れる。また、講義を行う通常日にお いて電力デマンドが発生しやすい。図から通常日においては最高気 温が $1{ }^{\circ} \mathrm{C}$ 上昇すると、約 $1.1 \%$ 最大需要電力が上昇することが分か った。

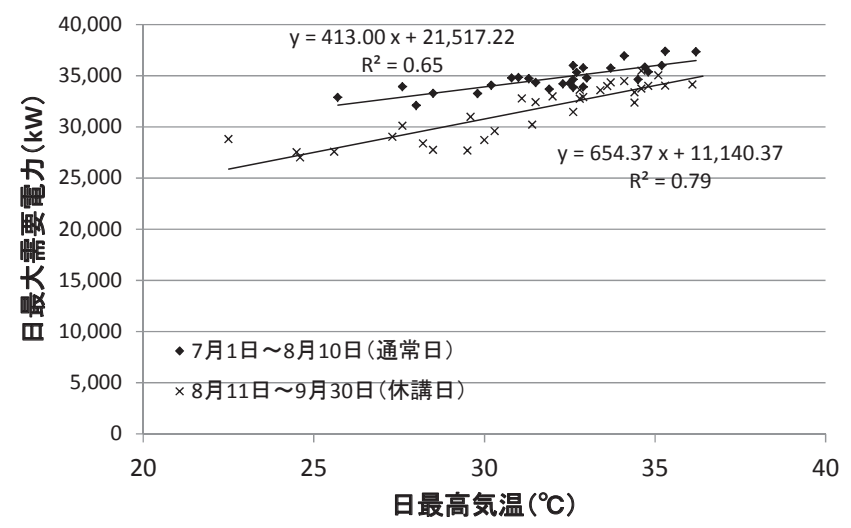

図 19 日最大需要電力と日最高気温の関係

\section{2 (4) 気温感応度分析}

図 20 には建物分類ごとの日電力消費量と日平均気温注 5) の関係を
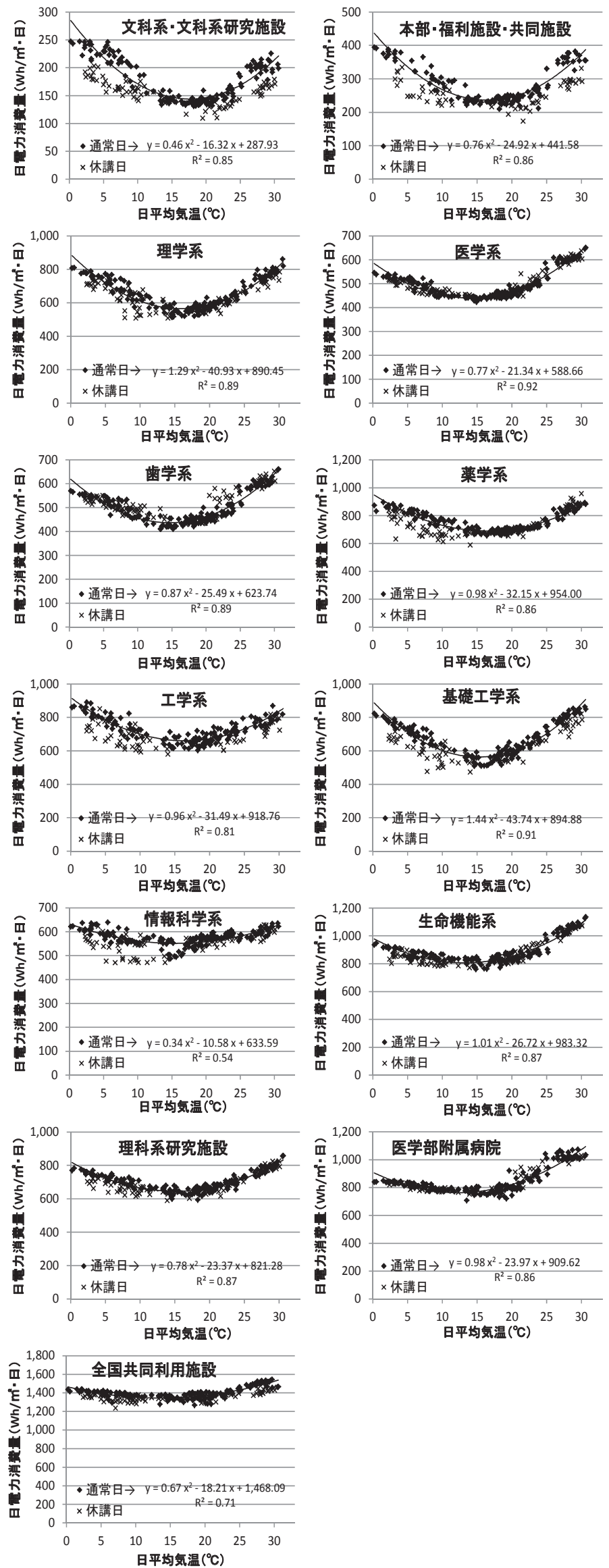

図 20 日電力消費量と日平均気温の関係 
示す注 6)。学部を抱える建物用途は休講日に日電力消費量が低下する 傾向が確認でき、特にカテゴリーI に顕著である。また、日電力消 費量が小さい建物分類ほど、相対として気温変動の影響を受けや寸 いことが分かる。さらに、カテゴリーIにおいては、冷房期より暖 房期において日電力消費量が多くなる傾向にあるが、これは内部発 熱量の少なさが一因と考えられる。

図 20 内には通常日の近似曲線を示すが、本曲線における日電力消 費量の最小ポイントは、空調需要が最も少なく、冷房／暖房需要の 分岐点であると考えることができる。ここで、この分岐点における 日平均気温（冷房／暖房需要の分岐温）と日消費電力量の関係を図 21 に示す。分岐温は建物分類によって最大 $5^{\circ} \mathrm{C}$ 程度の差（期間にし て一ヶ月程度）があり、日電力消費量が多いほど分岐温が低いこと が分かる。日電力消費量の多さは内部発熱量も多いことを意味し、 外気温が低い時期でも冷房需要が必要となることを示唆する。

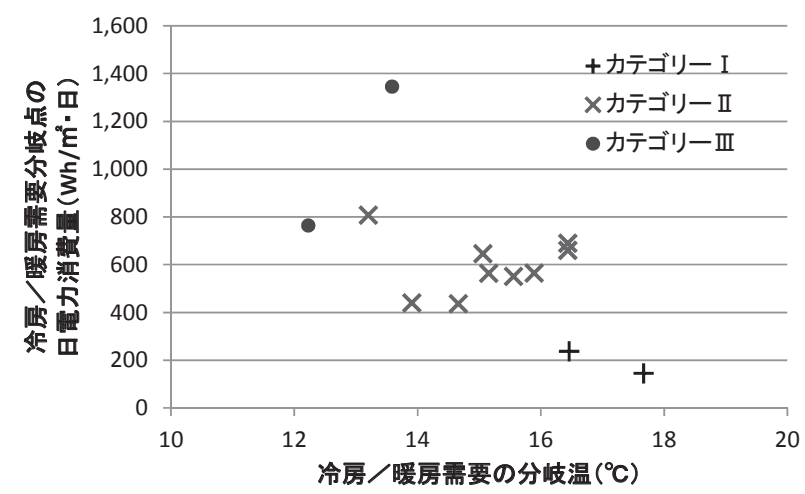

図 21 冷房／暖房需要分岐点の気温と日電力消費量の関係

\section{2（5） 年間電力消費量の内訳推計}

用途別のエネルギー消費量を推計する既往研究は多(が 5) 6)7) 10)、 時刻別の日負荷曲線を用いた事例は見当たらない。本項では、電力 可視化システムにより蓄積された実測データを用い、新たな視点で 年間の電力消費量の内訳推計を行う。

分離する内訳は 5.2 （3）にて示した「11)゙ース分」、「(2)活動分」、 「(3)非 $24 \mathrm{H}$ 空調」とする。なお、推計は表 1 で示した建物分類ごと に行う。推計手法は 5.2 (3) の考えに沿うものだが、図 22 に工学 系の 7 月の例を挙げ、電力消費量の内訳推計の過程を示す注 7 。

\section{・ステップ 1 :「11 ベース分」の算定}

人の活動に関係しない電力消費量は、各月の休日ベース電力量と 推測できる。よって、7 月においては 7 月休日ベース電力量を「(1) ベース分」とする。

\section{・ステップ 2 :「(2)活動分」の算定}

平日の需要が最も少ない非空調月を特定 (工学系の場合 4 月) し、 非空調月の平日 ・休日それぞれの電力日負荷曲線から非空調月の休 日ベース電力量を差し引いた電力消費量を人の活動に伴って必要と なる空調以外の電力消費量と考え、通年においてこの電力量を「(2) 活動分」とする。なお、月により活動量も多少の変化があることは 図20からも推察されるが、今回その影響は無視する。

\section{・ステップ 3 :「(3)非 $24 \mathrm{H}$ 空調」の算定}

ステップ 1、2 で求めた「(1)ベース分」および「(2)活動分」を 7 月の平日・休日それぞれにおいて全電力消費量から差し引き、残っ
た電力消費量を「(3)非 $24 \mathrm{H}$ 空調」とする。

以下、建物分類 $\mathrm{X}$ における $\mathrm{n}$ 月の電力消費量の内訳推計手法の定 義式を(3)～(5)に示す。
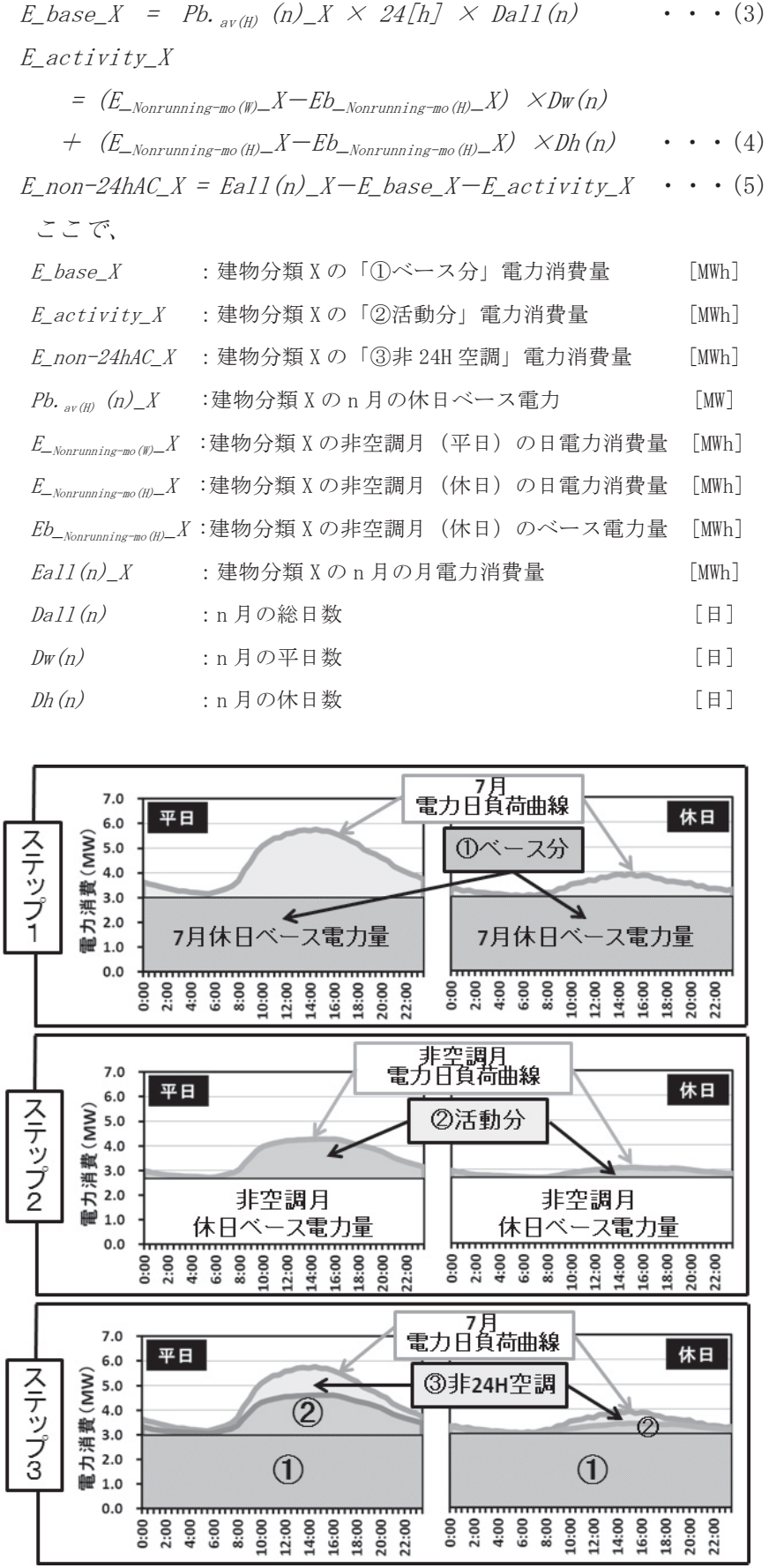

図 22 電力消費量の内訳推計の手法（工学系・ 7 月の例）

図 23 に大学全体での年間電力消費量の内訳推計結果を示す。(1)心゙ 一ス分：79\%、(2活動分：16\%、(3)非 $24 \mathrm{H}$ 空調：5％となっており、 人の活動に伴って必要となる電力消費量は $21 \%$ みで、 $79 \%$ も電 力量が人の活動に関係しない電力量であることが分かった。前述の 通り、大阪大学においては一次エネルギー消費量の約 $85 \%$ を電力が 占めるが、大学施設の省エネルギー・低炭素化を検討する上では、 電力のベース分の主な構成要素と推察される 24 時間稼働の実験機 
器、計算機類、フリーザー、医療機器及びそれらに付随する 24 時間 空調等の対策が重要と考えられる。

図 24 にカテゴリーごとに集計した、月別の電力消費量原単位の内 訳推計結果を示す。(1)ベース分の電力消費量はカテゴリーIII >カテ ゴリーII >カテゴリーI の順に多く顕著な差があるが、(2)活動分、

(3)非 $24 \mathrm{H}$ 空調についてはカテゴリー間の差は比較的小さいことが確 認できる。

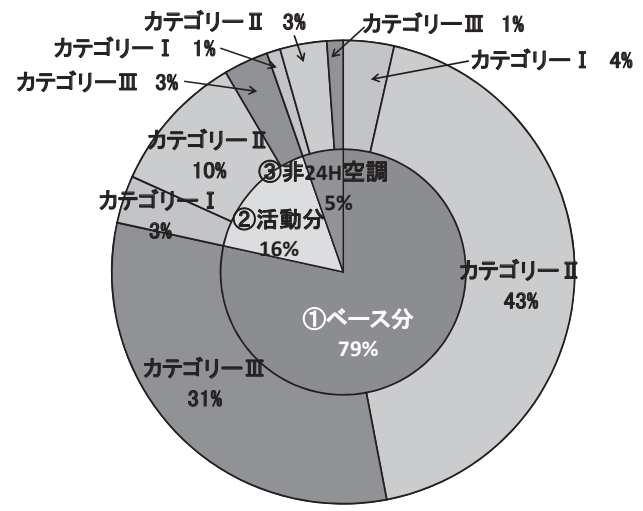

図 23 大阪大学における年間電力消費量の内訳推計結果
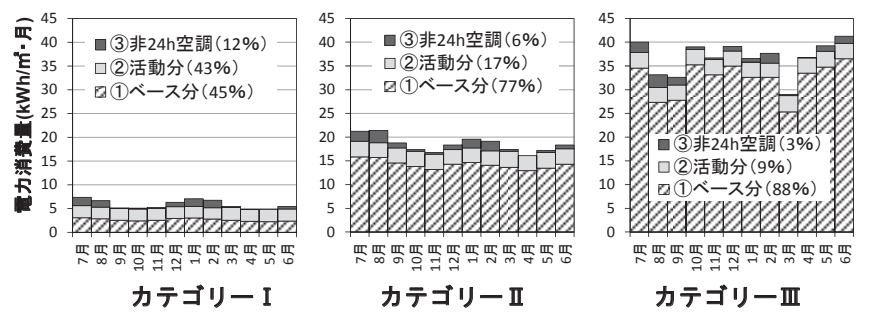

図 24 各カテゴリーの電力消費量原単位の内訳推計結果

建物分類ごとの特徵を把握するため、図 25 には、(1)ベース分の電 力消費量原単位と全電力消費量原単位の関係、図 26 には1 1 ベース分 以外の電力消費量原単位（2)活動分＋(3)非 $24 \mathrm{H}$ 空調）と全電力消費 量原単位の関係を示す。(1)ベース分以外の電力消費量原単位は人の 活動に伴って必要となる電力であるが、図 26 より、全電力消費量原 単位の差に比べると建物分類間の差は小さいことが分かる。一方、 図 25 より、(1)ベース分の電力消費量原単位が増加すると全電力消費 量原単位も顕著に増加する傾向が確認でき、(1)ベース分の大きさが、 年間の電力消費量に大きく影響していることが分かった。

\section{6. まとめ}

本研究では、大規模総合大学施設のエネルギー消費特性を明らか にすることを目的に、文科系学部・研究科、理科系学部・研究科、 大規模研究施設、附属病院等、多様な施設から成る大阪大学におい て、主要建物ごとの時刻別電力負荷曲線の実測データを活用し、各 種解析を行った。得られた主な知見を以下に示す。

・大学施設には多様な施設が混在しているが、文科系、理科系、大 規模施設ではエネルギー消費密度に顕著な差違があり、大阪大学 では理科系は文科系の 3 倍以上の年間一次エネルギー消費量原単 位がある。また理科系は $2,000 \sim 2,700 \mathrm{MJ} / \mathrm{m}^{2}$ ・年程度だが、フリ ーザーを多く保有する施設は $3,000 \mathrm{MJ} / \mathrm{m}^{2}$ ・年を超えるものが多

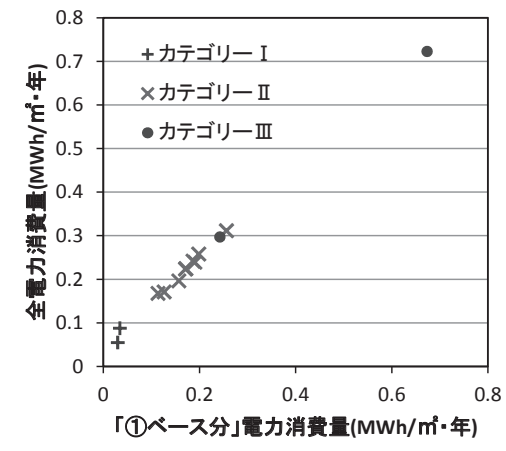

図 25

(1)ベース分の電力消費量原単位と全電力消費量原単位の関係

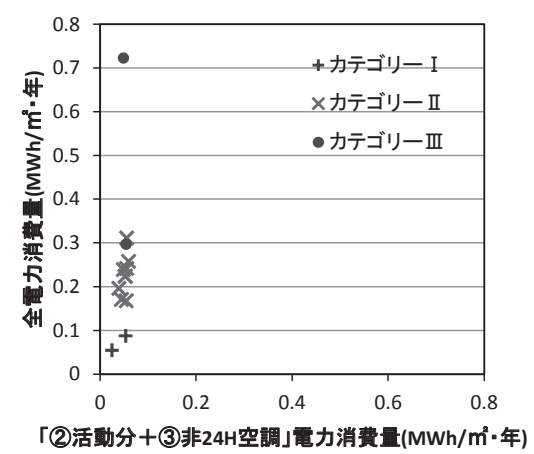

図 26

(2)活動分 + (3)非 $24 \mathrm{H}$ 空調の電力消費量原単位と

全電力消費量原単位の関係

く、24 時間稼働機器が影響しているものと推察される。

・ 1 月 1 日は年間で活動量が最も少ない日であると考えられるが、 実測の結果、一日を通してほぼ一定量の消費があることから、年 間を通して昼夜問わず人の活動に関わらず発生する電力消費が終 日一定量存在することが推察できる。

・夏季最大需要電力のうち、文科系は人の活動に伴う電力消費が $79 \%$ を占めるため、一般照明、OA 機器、一般空調等の節電対策 がピークカットに繋がるが、理科系については $53 \%$ が人の活動に 関係しない電力消費であり、ピークカットの視点においても 24 時間稼働機器の影響が大きいと推察される。

・大阪大学の夏季において、電力デマンドは講義が実施されている 通常日に発生しやすく、日最高気温が $1{ }^{\circ} \mathrm{C}$ 上昇すると日最大需要 電力は約 $1.1 \%$ 上昇する。

・日電力消費量が小さい建物分類ほど、外気温の変動が相対として 電力消費量に影響を与える。また、カテゴリーIにおいては冷房 期より暖房期の方が、日電力消費量が多くなる傾向がある。

・年間を通じての泠房／暖房需要の分岐外気温度は建物分類により 最大 $5{ }^{\circ} \mathrm{C}$ 程度の差（期間にして一ヶ月程度）があり、電力消費量 が多い施設ほど、外気温が低い時期でも冷房需要がある。

・大阪大学の年間電力消費量のうち、79\%が人の活動に関係しない 電力量であり、24 時間稼働機器の影響が非常に大きいと考えられ る。また、年間の電力消費量の大きさは、人の活動に伴って必要 となる電力消費量よりも、人の活動に関係しない電力消費量によ り大きく左右される。

ベース分の電力消費は、2 4 時間稼働機器の実験機器、計算機類、 フリーザー、医療機器、及びこれらに付随する 24 時間空調等が主 な要因と推察されるが、具体的な解明は今後の課題とする。 
注

注 1) 本文中に示す一次エネルギー換算係数は、電力 : $9.76[\mathrm{MJ} / \mathrm{kWh}]$ 、都市ガ ス : $45\left[\mathrm{MJ} / \mathrm{Nm}^{3}\right]$ で算出している。

注 2)データ久損日は排除している。

注 3) 休日とは土・日・祝日および年末年始を示す。

注 4) カテゴリーIIIは実験稼働の有無により電力量が大きく変動するため推計 を省略する。

注 5) 日最高気温、日平均気温は気象庁発表 ${ }^{9)}$ の「大阪府豊中」のデータによ る。

注 6) 分析にあたっては、土・日・祝日・年末年始・夏季一斉休業（お盆）期 間のデータは除く。全国共同利用施設のうち、実験稼働の有無により電力 量が大きく変動する核物理研究センターはデータから除いた。休講日は大 学が運営するキャンパス間の学内連絡バスの運休日を参考に設定した。

注 7) 全国共同利用施設については、エネルギー使用量が他施設に比べて多い ことから部局ごとに推計を行った。なお、核物理研究センターにおいては、 実験稼働の有無により電力量が大きく変動しており、その影響を考慮する ため、「(1)ベース分」を算出する際には休日ベース電力量だけでなく、平 日ベース電力量も用いて平日・休日別に推計を行った。また非空調月につ いては、カテゴリーII や医学部附属病院と同じ 4 月に設定した。

\section{本研究に関する既往発表論文}

$※ 1 ）$ 下田吉之, 宮崎正幸, 大橋巧 : 大学施設の電力消費特性に関寸る研究 その 1 電力可視化システムを用いた消費特性分析, 日本建築学会大会学術 講演梗概集，D-1， pp. 1143-1144，2012.9

$※ 2 ）$ 大橋巧, 宮崎正幸, 下田吉之：大学施設の電力消費特性に関寸る研究 その 3 用途別電力消費量の推計, 日本建築学会大会学術講演梗概集, D-1, pp. 1147-1148, 2012.9

\section{参考文献}

1）河野匡志, 柳原隆司, 花木啓祐, 磯部雅彦, 坂本雄三 : 国立大学施設におけ
る環境負荷低減手法に関する研究 東京大学における $\mathrm{CO}_{2}$ 排出量削減に向 けた実効ある対策の計画と実践の事例, 日本建築学会環境系論文集, Vol. 76, No. 666 , pp. $727-734,2011.8$

2）李演生, 赤坂泰義, 渡辺俊行, 福田健一, 江島伊佐朗 : 省エネルギー手法に よる空調用エネルギー消費原単位の削減効果と $\mathrm{PAL} \cdot \mathrm{CEC} / \mathrm{AC}$ 評価 大学キ ヤンパスの環境・省エネルギー計画に関する研究, 日本建築学会環境系論 文集，No. 564，pp. 55-62，2003.2

3) Yuan SU, Hiroto TAKAGUCHI, Fulin WANG:EVALUATION ON ENERGY CONSUMPTION CHARACTERISTICS AND EFFECT OF ENERGY CONSERVATION MEASURES IN UNIVERSITY CUMPUS BUILDINGS IN NORTHERN CHINA, 日本建築学会環境系論文集, Vol.77, No. 677, pp. 605-614, 2012.7

4) 永峯章, 高草木明, 成實悠樹, 吉野大輔 : 東洋大学の 4 箇所のキャンパスに おけるエネルギー消費量に関する調査研究, 日本建築学会環境系論文集, Vol. 75, No. 653, pp. 661-668, 2010.7

5）迫田一昭, 河野匡志, 花木啓祐, 野城智也, 磯部雅彦: 大学キャンパスにお ける二酸化炭素削減策の立案・実行-東京大学サステイナブルキャンパスプ ロジェクトー, エネルギー・資源学会技術報告, Vol. 30, No. 4, pp. 240-243, 2009. 7

6）宋城基 : 多様な空調システムが混在する大学キャンパスのエネルギー消 費実態調查研究，空気調和・衛生工学会論文集，No. 156, pp. 1-9, 2010.3

7） 三瀬農士, 佐藤春樹 : 慶應義塾大学湘南藤沢キャンパスにおける電力およ び冷暖房需要の推定, 日本建築学会環境系論文集, No. 609, pp. 55-62, 2006. 11

8）財団法人省エネルギーセンター診断指導部：ビルの省エネルギーガイド ブック 2011-2012, P. 7, 2012.1

9）気象庁： http://www.data.jma.go.jp/obd/stats/etrn/index.php, 入手 2012-7-2

10）陳超, 渡辺俊行, 龍有二, 赤坂泰義 : 各種業務施設の空調用エネルギー消 費量に関する研究，日本建築学会計画系論文集, No. 501, pp. 61-68, 1997. 11

（2012年 8 月 3 日原稿受理，2012年10月29日採用決定） 